\title{
Sequential Explanatory Analysis of Headmaster's Performance Investigated from Integrity, Decision Making and Transformational Leadership
}

\author{
H. TB. M. Suherman*, Soewarto Hardhienata, Rita Retnowati \\ Post Graduate Program, Universitas Pakuan Bogor, Indonesia
}

*Corresponding Author: H. TB. M. Suherman, Post Graduate Program, Universitas Pakuan Bogor, Indonesia

\begin{abstract}
The purpose of this study is to find practical efforts to improve the performance of school headmasters by examining the variables associated with it, namely integrity, decision making and transformational leadership. This study uses a model sequential explanatory method and SITOREM analysis. The study population consisted of 224 Elementary School headmasters in Serang, Indonesia, and 144 samples were selected randomly. Quantitative data were collected through questionnaires and statistical analysis methods using regression and correlation. The SITOREM analysis is used to help make recommendations and determine the priority order for the improvements needed. Qualitative data were collected through interviews, observations, documentation studies and focus group discussions. The results of the quantitative stage show that there are positive and significant relationships between the three independent variables and the performance of the headmaster, respectively, based on the strength of the relationship with the headmaster's performance as follows: 1) decision making $\left(r_{y 2}=0.890, \rho<0.05\right)$; 2) integrity $\left(r_{y 1}=0.739, \rho<0.05\right)$; and 3) transformational leadership $\left(r_{y 3}=0.713, \rho<0.05\right)$. Qualitative data shows the same tendency that the improvement of headmasters' performance can be done through increasing decision making, integrity, and transformational leadership. The results of the SITOREM analysis show that the priority components are improved from decision making, integrity, transformational leadership and headmasters' performance.
\end{abstract}

Keywords: headmaster performance, integrity, decision making, transformational leadership, SITOREM.

\section{INTRODUCTION}

Education provides a huge contribution to the progress and development of the nation's personality. Education is a form of investment in human capital, which determines the quality of human resources (HR) of a nation. A government that has succeeded in building the foundations of national education well is expected to contribute to the progress in various other fields. This shows that efforts to improve the quality of education must be carried out in a systematic and directed manner based on national interests that refer to scientific progress.

Headmasters whose data show excellent performance are characterized by several things, such as: being able to run the wheels of the school organization well, as well as having the ability as educators, school managers, administrative managers, with high integrity, leadership style and also acting as a coach. If the headmaster can perform optimally in these conditions, then his performance will be excellent and have an impact on improving the quality of school education he leads.

In reality, the performance of the headmaster must still be further improved. Indications that the performance of school headmasters are not yet optimal can be seen from the lack of desire to develop themselves, increase self-competence, lead schools well, lack integrity in their work and have not shown many breakthroughs or innovations that can improve performance and self-competence and improve the quality of education in schools. Therefore, efforts are needed to improve the performance of school headmasters.

Preliminary survey results obtained from 30 teachers from several Elementary School in 6 subdistricts in Serang City reveal that there are indications of school performance problems. Based on data from the Serang City Education Office, it is known that the performance level of elementary school headmasters in Serang City as a whole has only reached 58\%, with detailed score 
achievements as follows: planning (59\%), supervision (60\%), motivator (58\%), management education (58\%), the role of educators (58\%), staffing (57\%), and innovation (59\%). This shows that the performance of Elementary School headmasters in Serang City still needs to be improved to be able to encourage educational progress.

The activity of carrying out the headmaster's duties is related to the leadership style adopted. Transformational leadership style involves concrete actions to subordinates to perform optimally in achieving school goals. Transformational leadership intensively stimulates the intellectual of the teacher so that new ideas will be obtained that support the school headmaster in innovating. Headmasters who consider the opinions and conditions of individual teachers will be helped in motivating teachers because they better understand the needs of each teacher. Charismatic transformational leadership styles support the smooth implementation of instructions and coordination of tasks between teachers because they tend to be obedient.

Headmaster competence consists of managerial skill, personality, social, professional and entrepreneurship. Professional school headmasters support their role as educators as well as managers who are capable of managing school operations. Headmasters who have strong personalities will make it easier for them to interact with teachers and employees, motivating them to work harder. Headmasters who have high entrepreneurial spirit will encourage teachers and employees to make meaningful innovations for the progress of the school.

Based on the background, problem identification and problem limitation, the formulation of the problem in this study are:

- Is there a relationship between integrity and the performance of the headmaster?

- Is there a relationship between decision making and the performance of the headmaster?

- Is there a relationship between transformational leadership and the performance of the headmaster?

- Is there a relationship between integrity, decision making and transformational leadership together with the performance of the headmaster?

\section{LITERATURE REVIEW}

\subsection{Performance}

Shahid (2013), states that performance is the result of the quality and quantity of work achieved by an employee in carrying out their duties following the responsibilities given to him. Protas (2013) explains that performance is the ability to perform a particular skill.The performance of a school headmaster is the result of a synergy of internal organizational environmental factors, external environment, and internal employee factors. Besides the excellent performance of the headmaster isviewed from how he arranged the school to achieve the expected goals. In managerial activities that include planning, implementation, administration, reports, accountability, guidance and supervision. Managerial performance variables are measured using an instrument self-rating developed by Palanski (2011), which measures eight dimensions, namely planning, investigation, coordination, evaluation, supervision, staff selection, negotiation, and representation.

\subsection{Integrity}

According to Lee (2012), integrity is a quality that underlies public trust and is a benchmark for the institution or organization in testing all its decisions. Integrity requires an employee to be honest and transparent, brave, wise and responsible in carrying out tasks, the fourth of which is needed to build trust and provide the basis for reliable decision making.

While Prottas (2013) states that integrity behaviour is positioned related to organizational performance because employee trust in their leaders will positively influence employee attitudes such as job satisfaction, organizational commitment, willingness to promote and implement changes that are accountable for involvement work. Integrity in schools cannot be separated from discussions 
about the competencies held by the headmaster to be able to produce an excellent performance in schools. The headmaster is said to have good integrity, the more he pays attention to his competence and vice versa, the more he has good ability he also pays attention to his integrity.

\subsection{Decision Making}

According to Buchanan (2010), decision making defined as the choice between alternative decision choices. This can be thought of as the result of mental or cognitive processes (remembering, thinking and evaluating) that lead to the choice of actions among several alternatives. Decision Making involves mapping the possible consequences of decisions, determining individual factors, and choosing the best course of action that must be taken. A decision is a definite answer to a question. Decisions can also be in the form of efforts towards implementation that deviate greatly from the original plan. Decision making by the headmaster should be done to improve the quality of education. According to Ahmad Munib (2013: 2), the quality of school leadership is believed to be the key to school success. Therefore all things need to be decided based on appropriate considerations and context. Decision Making aims to improve education include: 1. planning and improving learning, 2. management decision making, and 3. developing human resources needed to achieve better educational outcomes.

\subsection{Transformational Leadership}

Transformational leadership is built from two words: leadership and transformational. Leadership is an action taken by someone to coordinate, direct and influence others in choosing and achieving predetermined goals. The term transformation comes from the word to transform, which means transforming or changing something into another different form, for example transforming vision into reality, or changing something that is potential to be actual (Gumusluoglu, 2009).

Based on the study of theories and concepts relating to research variables, namely performance, integrity, decision making, and transformational leadership, the following hypotheses can be formulated:

- There is a positive relationship between integrity and performance of school headmasters.

- There is a positive relationship between decision making and the performance of the headmaster.

- There is a positive relationship between transformational leadership and the performance of school headmasters.

- There is a positive relationship between integrity, decision making and transformational leadership together with the performance of the headmaster.

\section{MeThodologY}

This study uses a sequential explanatory mixed-method, which is a research method that combines quantitative methods and qualitative methods to be used sequentially beginning with the quantitative stage and then followed by the qualitative stage, to obtain more comprehensive, valid, reliable and objective data. The method used in this study is a survey method with a correlational approach. The research variables consisted of three independent variables, namely Integrity $\left(\mathrm{X}_{1}\right)$, Decision Making $\left(\mathrm{X}_{2}\right)$, and Transformational Leadership $\left(\mathrm{X}_{3}\right)$, while the dependent variable was School Headmaster Performance (Y).

Sources of data in the study were obtained from each Public Elementary School in the City of Serang, with crucial informants determined namely Supervisors, companion informants namely Deputy Headmasters and triangulation informants, namely Supervisors. Data collection techniques at the qualitative research stage were carried out through in-depth interviews (in-depth interviews) with FGD (Focus Group Discussion), observations, and documentation studies.

Data analysis can be done in two ways, namely: a) The stage of quantitative data on research results that have been obtained, evaluated using factor analysis, validated which then produces information on whether there are findings which will then be used as a reference question for the deepening of more detailed data; and b) Phase qualitative data that has been obtained, analyzed to produce data 
findings that complement each other, expand, deepen or even weaken, invalidate or contradict quantitative data.

Furthermore, the implementation of the analysis and discussion of quantitative and qualitative research results employs the SITOREM method (Hardhienata, 2017). Based on the results of the SITOREM analysis, it can be determined the priority of suggestions and action plans.

\section{RESULTS AND DISCUSSION}

\subsection{Relationship between Integrity and Primary School Headmaster Performance}

Results of the research and hypothesis testing show the strength of the relationship between Integrity variables and Headmaster Performance demonstrated by the correlation coefficient $r_{\mathrm{y} .1}=0.789$ with the coefficient of determination $\mathrm{r}_{\mathrm{y} .1}^{2}=0.622$. This means that integrity contributed $62.2 \%$ to the Headmaster's Performance, while $37.8 \%$ of the Headmaster's Performance was influenced by other factors. The findings obtained in this study indicate that the integrity of the Headmaster to find out how well a headmaster in implementing the leadership wheel in schools. Simple linear regression analysis between Integrity and Headmaster's Performance produces a line equation $\hat{Y}=48.32+$ $0.64 \mathrm{X} 1$, which is stated significant so that this equation can be used to predict headmasters' performance through the integrity variable.

Integrity is a quality that underlies public trust and is a benchmark for an institution or organization in testing all its decisions. In the school environment, the headmaster's integrity will significantly affect internal and external trust, which then impacts on various conditions within the organization. This is in line with the theory put forward by Prottas (2013) where integrity behaviour is positioned related to organizational performance because employee trust in their leaders will positively influence employee attitudes such as job satisfaction, organizational commitment, willingness to promote and implement changes that are accountable for work involvement. Based on this, it can be said that the higher the integrity of headmasters, the higher the trust of internal school residents, especially teachers, so that they will be willing to carry out the plans set by the headmaster, committed to advancing the school together towards the achievement of the school's goals.

The quantitative data above is strengthened by the results of observational data, interviews and documentation studies on qualitative research which can be concluded that the Integrity of the Headmaster of the Primary Elementary Schools in Serang City observed has characteristics and characteristics that are in accordance with the work environment in each school which is the object of research in order to improve the performance of the Headmaster of Public Elementary Schools in achieving the planned objectives. Therefore Integrity Headmaster qualitatively in the field has the same tendency with Integrity Headmaster quantitatively.

Based on the explanation, it can be concluded that the better the integrity of a school headmaster, the better the performance of the school headmaster. Facts and data findings in the analysis of this study further support previous findings regarding the existence of a positive relationship between Integrity and Performance.

\subsection{The Relationship between Decision Making to Headmaster Performance}

Therelationship between the variable of decision making with the headmaster's performance is shown by the correlation coefficient $r_{y .2}=0.890$ with the coefficient of determination $r_{y .2}^{2}=0.792$. This means that decision making contributed $79.2 \%$ to the headmaster's performance, while $19.8 \%$ the headmaster's performance was influenced by other factors. To test the significance of a positive relationship between decision making and theheadmaster's performance required a correlation coefficient significance test, namely the $t$-test. If ${ }_{\text {arithmetic }}>t_{a b l e}$, then the correlation coefficient is declared significant.

Based on the calculation results obtained $t_{\text {count }}=11.749$ while $t_{\text {table }}=1.977$ at a significance level $\alpha=$ 0.05 with $\mathrm{df}=142$. Because count $>\mathrm{t}_{\text {table }}$, then the correlation coefficient between decision making and headmaster performance is stated to be very significant. The findings obtained in this study indicate that there is an indication of the contribution of the decision making of the headmaster to the performance of the headmaster in carrying out their duties and roles in a school. With the decision (the decision) is good in decision making can improve the performance of headmasters and overall 
school performance. Every decision made by the headmaster should be to improve the quality of education in the school.

The ability of a school headmaster to make a decision is greatly influenced by how much authority is given. But what matters most is not much or little authority, but whether the headmaster can use the authority given to him to make the best decision. Truong (2017) states that the authority is committed to improve education standards and achievement and the views of teaching staff in schools are crucial instruments in achieving goals. This means that every decision to be determined by a school headmaster must coordinate all interests and always be guided by the progress of the school and to carry out the vision and mission of the school.

This is following the theory put forward by Patrinos (2009), school headmasters are not merely symbols, but actual figures are expected to be an example for the school community in realizing the vision and mission of the school. The headmaster is a person who is considered as a leader and innovator, so the quality of leadership is also considered important as a key to the success of the school. Therefore, all decisions made by the headmaster must be decided based on consideration and the right context. Decision making aims to improve education include: 1) planning and improving learning; 2) management decision making; 3) development of human resources needed to achieve better educational outcomes. Thus this theory strengthens the relationship between decision making and performance.

The quantitative data above is strengthened by the results of observational data, interviews and documentation studies on qualitative research which can be concluded that the decision making headmaster of primary schools in Serang city that are observed to have characteristics, characteristics and specificities in accordance with the developing environment in each school that is the object research in order to improve the performance of the headmaster of public elementary schools in achieving the planned objectives. Therefore decision making headmaster qualitatively in the field has the same tendency with decision making headmaster quantitatively.

Based on the description above, it can be concluded that the higher the quality of the decision making headmaster will also increase the performance of the headmaster. Thus the findings of facts and data in the analysis of this study further support previous findings regarding the positive relationship between decision making and performance.

\subsection{The Relationship between Transformational Leadership to Primary School Headmaster Performance}

The value of the coefficient of determination between transformational leadershipheadmaster with school headmaster performance is equal to 0.555 . This means that transformational leadership contributes $55.5 \%$ to the headmaster's performance, while $44.5 \%$ of the headmaster's performance is influenced by other factors.

Based on the calculation results obtained $\mathrm{t}_{\text {count }}=15.195$ while $\mathrm{t}_{\text {tables }}=1.977$ at a significance level $\alpha=$ 0.05 with $\mathrm{df}=136$. Because the value is $>\mathrm{t}_{\text {table }}$, the correlation coefficient between transformational leadership with headmaster performance is stated to be very significant. From the results of regression calculations it can be seen that the performance of school headmasters while at school can be influenced by the headmaster transformational leadership style. This shows that headmaster transformational leadership has a critical role in the achievement of the headmaster's performance. The choice of leadership style used by a school headmaster can influence all the activities of group members and determine the group's ideology.

This is consistent with the theory put forward by Sun (2014) stating that transformational leadership is a process of mutually reinforcing between leaders and followers to a higher level of morality and motivation. Transformational leadership is not only direct and top-down (from top to bottom), but can also be observed indirectly, bottom-up, and horizontally.

Transformational leadership is related to strong self-identification, vision creation, and the relationship between leaders and followers. Transformational leaders define the need for change, create new visions, mobilize commitments to carry out visions and transform followers at both the individual and organizational level. In the implementation of leadership in schools conducted by the 
headmaster, transformational leadership is an essential component, with a good transformational leadership of the headmaster it will be easier to direct and manage the school so that it will have an impact on the headmaster's performance which is getting better like in contemporary business society (Al-Sharafi, and Rajiani, I., 2013).

The quantitative data above is strengthened by the results of observational data, interviews and documentation studies on qualitative research which can be concluded that the transformational leadership of the primary school headmaster in Serang city that is observed has characteristics, characteristics and specificities in accordance with the developing environment in each school that is the object research in order to improve the performance of the headmaster of public elementary schools in achieving the planned objectives. Therefore the qualitative transformational leadership of the headmaster in the field has the same tendency as the quantitative transformational leadership of the headmaster.

Based on the description above, it can be concluded that the higher the headmaster transformational leadership, the more the headmaster's performance results in the school. Thus the findings of facts and data in the analysis of this study further support previous findings regarding the positive relationship between the transformational leadership of the headmaster and the headmaster's performance.

\subsection{Relationship between Integrity, Decision Making and Transformational Leadership Headmasters Together to the Performance of Headmasters of State Primary Schools}

The results of the calculation of hypothesis testing indicate the value of the correlation coefficient between integrity, decision making and transformational leadership together with the headmaster's performance of 0.902 with a coefficient of determination $\mathrm{r}_{\mathrm{y} .1}^{2}=0.814$. This means that integrity, decision making and transformational leadership together contributed $81.4 \%$ to the headmaster's performance, while $18.6 \%$ the performance of the headmaster was influenced by other factors.

The findings obtained in this study indicate that if the headmaster in his work has good integrity by being honest and transparent, brave and wise and responsible in carrying out his work, then it will result in the realization of an excellent performance in terms of the quantity and quality of results work as expected. According to Yayus (2010) describes the integrity of behaviour as a trait-based on the perception of followers. Many studies have adopted the definition of integrity in terms of consistency or what is referred to as behavioural integrity and perceived regularity patterns between words and actions. This means that if a school headmaster has good integrity, then his subordinates will join together to achieve the goals that have been set together.

Decision making the headmaster should be to improve the quality of education. According Legare (2011), the school headmaster is not just a symbol, but the actual figure is expected to be an example for the school community in realizing the vision and mission of the school. Besides, the headmaster must have transformational leadership. The role of the headmaster in the transformational leadership style helps achieve the performance of the headmaster which is realized by how much the leader provides direction, transformation of the organization's vision and mission appropriately, which prioritizes the provision of opportunities that encourage all elements or elements of the school to work together on the basis of a noble value system, so that all aspects in the school are willing to participate optimally in achieving the vision of the school.

From the results of calculations in this study, the coefficient of determination of the correlation between integrity, decision making and transformational leadership together with the performance of the headmaster is 0.797 . This means that $79.7 \%$ of the headmaster's performance is the result of the work of the headmaster's integrity, decision making headmaster and transformational leadership the headmaster, while $20.3 \%$ was contributed by other variables that have a relationship with the improvement of the headmaster's performance.

\section{SITOREM ANALYSIS}

Based on the figure bellow as a follow up of this study made an action plan or an activity that aims to design programs that can be an alternative in order to increase school headmaster so that educational goals can be achieved more efficiently (Hardhienata, 2017). 


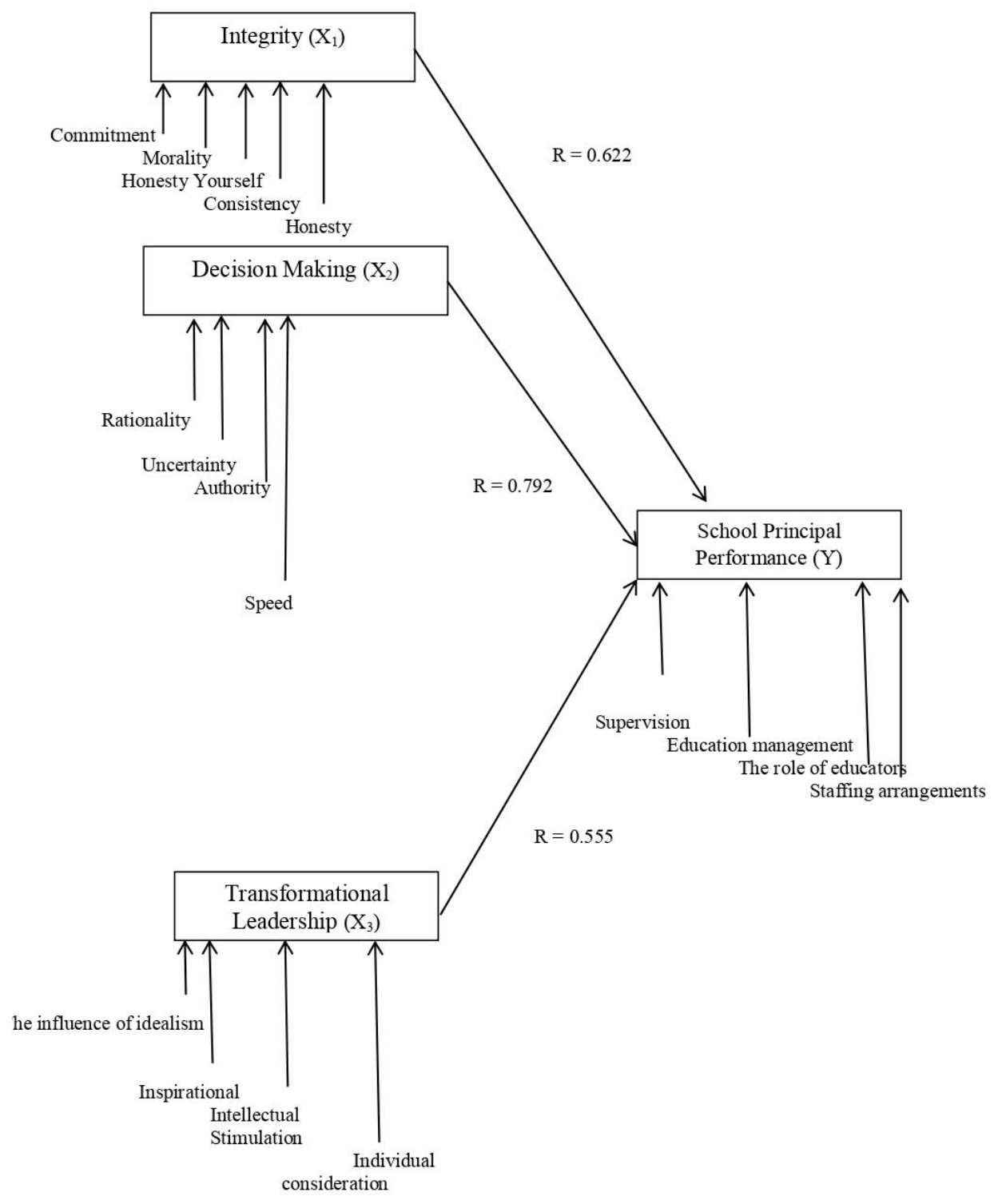

Figure1: Analysis SITOREM (Scientific Identification Theory for Operational Research in Education)

\section{CONCLUSION}

Based on the results of research at the quantitative stage and the qualitative research stage, it can be concluded that this study has found efforts to improve the performance of school headmasters, based on identification:

- There is a positive and very significant relationship between integrity and school headmaster performance, which means that the higher the integrity of the headmaster the school will therefore also increase the headmaster's performance and vice versa.

- There is a positive and very significant relationship between decision making and the headmaster's performance, which means that the higher the decision-making headmaster will lead to an increase in the headmaster's performance and vice versa.

- There is a positive and very significant relationship between transformational leadership and school headmaster performance, which means that the higher the headmaster transformational leadership will lead to an increase in the headmaster's performance and vice versa.

- There is a positive and very significant relationship between integrity, decision making and transformational leadership together with the headmaster's performance, which means that the higher the integrity, decision making and transformational leadership of the headmaster together will lead to an increase in the headmaster's performance and vice versa. 


\section{REFERENCES}

[1] Al-Sharafi, H. and Rajiani, I., 2013. Leadership practices and talent turnover: Study on Yemeni organisations. Business and Management Research, 2(3), pp.60-67.

[2] Buchanan, D.A. and Huczynski, A.A., 2010. Organizational behaviour. Pearson UK.Gumusluoglu, L. and Ilsev, A., 2009. Transformational leadership, creativity, and organizational innovation. Journal of business research, 62(4), pp.461-473.

[3] Hardhienata, S., 2017, January.The development of scientific identification theory to conduct operation research in education management. In IOP Conference Series: Materials Science and Engineering (Vol. 166, No. 1, p. 012007). IOP Publishing.

[4] Lee-Ross, D. and Lashley, C., 2012. Organization behaviour for leisure services. Routledge.

[5] Légaré, F., Stacey, D., Pouliot, S., Gauvin, F.P., Desroches, S., Kryworuchko, J., Dunn, S., Elwyn, G., Frosch, D., Gagnon, M.P. and Harrison, M.B., 2011. Interprofessionalism and shared decision-making in primary care: a stepwise approach towards a new model. Journal of interprofessional care, 25(1), pp.1825 .

[6] Shahid, A. and Azhar, S.M., 2013. Integrity \& trust: The defining principles of great workplaces. Journal of Management Research, 5(4), p.64.

[7] Sun, M. and Yang, Y., 2014.Headmasters' transformational leadership in school improvement. International Journal of Educational Management.

[8] Patrinos, H.A., Barrera-Osorio, F. and Fasih, T., 2009. Decentralized decision-making in schools: The theory and evidence on school-based management. The World Bank.

[9] Palanski, M.E. and Yammarino, F.J., 2011. Impact of behavioral integrity on follower job performance: A three-study examination. The Leadership Quarterly, 22(4), pp.765-786.

[10] Prottas, D.J., 2013. Relationships among employee perception of their manager's behavioral integrity, moral distress, and employee attitudes and well-being. Journal of Business Ethics, 113(1), pp.51-60.

[11] Truong, T.D., Hallinger, P. and Sanga, K., 2017. Confucian values and school leadership in Vietnam: Exploring the influence of culture on headmaster decision making. Educational Management Administration \& Leadership, 45(1), pp.77-100.

[12] Yavuz, M., 2010. Effectiveness of supervisions conducted by primary education supervisors according to school headmasters' evaluations. The Journal of educational research, 103(6), pp.371-378.

Citation: H. TB. M. Suherman, et.al. "Sequential Explanatory Analysis of Headmaster's Performance Investigated from Integrity, Decision Making and Transformational Leadership" International Journal of Managerial Studies and Research (IJMSR), vol 7, no. 12, 2019, pp. 24-31. doi: http://dx.doi.org/10.20431/23490349.0712004.

Copyright: (1) 2019 Authors. This is an open-access article distributed under the terms of the Creative Commons Attribution License, which permits unrestricted use, distribution, and reproduction in any medium, provided the original author and source are credited. 